症例

\title{
腹腔鏡下に切除した脾原発 $\mathrm{EBV}$ 関連 炎症性偽腫瘍様濾胞樹状細胞性腫瘍の 1 例
}

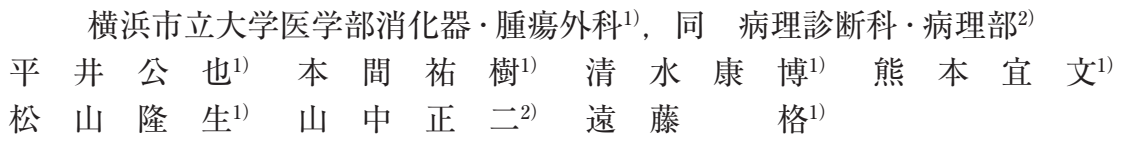

患者は53歳，女性．尿崩症の精査時に施行したCTで偶然脾腫瘍を認めたため，当科 へ紹介となった．腹部造影 CTで脾臟内に不均一な造影効果を伴う最大径 $7.7 \mathrm{~cm}$ 大の腫 瘤を認め, PET-CTで同部位に異常集積を認めた，MRIを施行したが画像所見では確 定診断に至らず，悪性を否定し得ないことから診断的治療のため腹腔鏡下脾臟摘出術を 施行した。病理組織学的検査で高度な炎症性細胞浸潤と紡錘形細胞の増生を認め, 免疫 染色では CD $21 \cdot \mathrm{CD} 35 \cdot \mathrm{CD} 23 \cdot \mathrm{EBER}$ 陽性を示した．以上から，脾原発の EBV 関連炎 症性偽腫瘍様滤胞樹状細胞性腫瘍と診断した。 EBV 関連炎症性偽腫瘍様滤胞樹状細胞 性腫瘍は炎症性偽腫瘍と滤胞樹状細胞肉腫の特徵を持ち, EBV 感染を認める稀な腫瘍 である。鑑別困難な脾腫瘍においては，EBV 関連炎症性偽腫瘍様滤胞樹状細胞性腫瘍 も稀ながら念頭に置くべきであり, 腹腔鏡下脾臓摘出術は適切な治療選択肢と考える.

索引用語：脾臓, 腹腔鏡, 炎症性偽腫瘍様滤胞樹状細胞性腫瘍

\section{緒 言}

Epstein-Barr virus（EBV）関連炎症性偽腫瘍様滤 胞樹状細胞性腫瘍は炎症性偽腫瘍と滤胞樹状細胞肉腫 の特徵を持ち, $\mathrm{EBV}$ 感染を認める稀な腫瘍である. 今回われわれは, 腹腔鏡にて摘出した脾原発 $\mathrm{EBV}$ 関 連炎症性偽腫瘍様滤胞樹状細胞性腫瘍の 1 例を経験し たので，文献的考察を加え報告する．

\section{症例}

患者 : 53歳, 女性.

主訴：なし。

既往歴：中枢性尿崩症.

家族歴：特記事項なし.

現病歴: 尿崩症の精查時に施行したCTで偶発的に 脾腫瘍を認め, PET-CTでも同部位に FDGの異常集 積を認めたことから悪性を疑い, 当科へ紹介となった.

受診時現症：身長 $167.2 \mathrm{~cm}$, 体重70.0kg. 発熱や体 重減少, リンパ節腫脹は認めなかった。

血液生化学検査 : 腫瘍マーカーや免疫グロブリンを

2020 年 3 月 17 日受付 2020 年 6 月 5 日採用

〈所属施設住所〉

₹236-0004 横浜市金沢区福浦 3-9
含め, 特記すべき異常は認めなかった.

腹部造影 $\mathrm{CT}$ : 脾臓内に不均一な造影効果を伴う 5.5 $\times 7.7 \times 6.5 \mathrm{~cm}$ 大の腫瘤を認め, 腫瘤辺縁は分節状で造 影早期相にて被膜様の増強効果を認めた（Fig. 1a).

PET-CT : 脾臟に濃度不均一な腫瘤があり, 同部 位にFDGの異常集積（SUVmax13.8）を認めた（Fig. 1b). その他の臓器に異常集積は認めなかった。

腹部MRI：T1 強調像で脾実質に近い信号, T2 強 調像で軽度の低信号を基調とし内部に不整形の高信号 を認めた。拡散強調像では脾実質より若干劣る高信号 を示し，ADC mapで低信号を呈し拡散制限を認めた (Fig. 2).

画像所見のみでは確定診断に至らず，悪性腫瘍を否 定し得ないことから診断的治療のため腹腔鏡下脾臓摘 出術を計画した。

手術所見 : 腫大した脾臓により膵尾部が屈曲するよ うに圧排され, 脾門部で膵尾部と脾臓の強固な癒着を 認めた。脾門部での剥離操作が困難であったため, 出 血や術後膵液瘦, 脾被膜損傷による悪性細胞の腹腔内 散布を考慮し一部膵組織を付けるように切除し, 膵尾 部合併切除とした.

病理組織学的検査: 脾臓内に白色充実性を呈した 


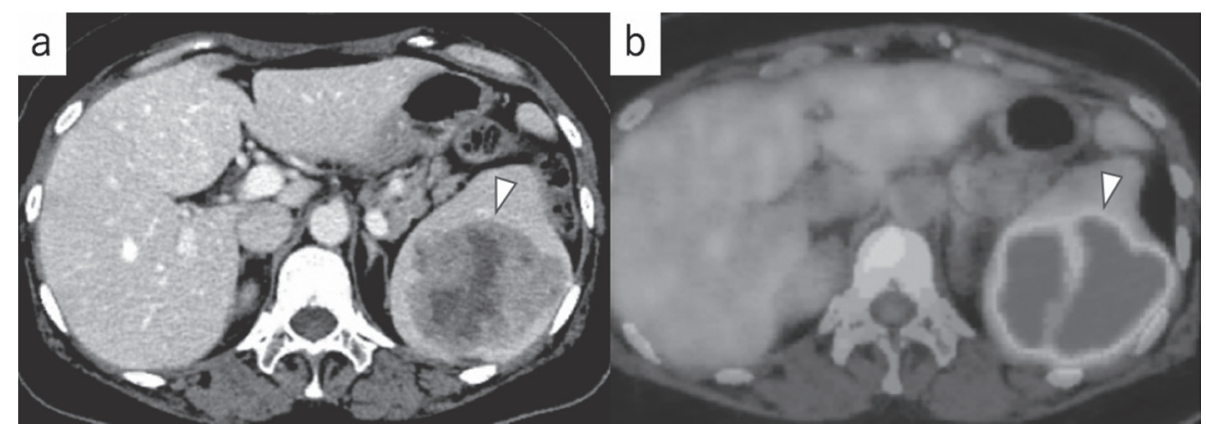

Fig. 1 腹部 CT

$\mathrm{a}$ ：造影 CT. 脾臓内に不均一な造影効果を伴う $5.5 \times 7.7 \times 6.5 \mathrm{~cm}$ 大の腫瘤を認めた.

b : PET-CT. 腫瘤に一致して異常集積を認めた（SUVmax13.8）.

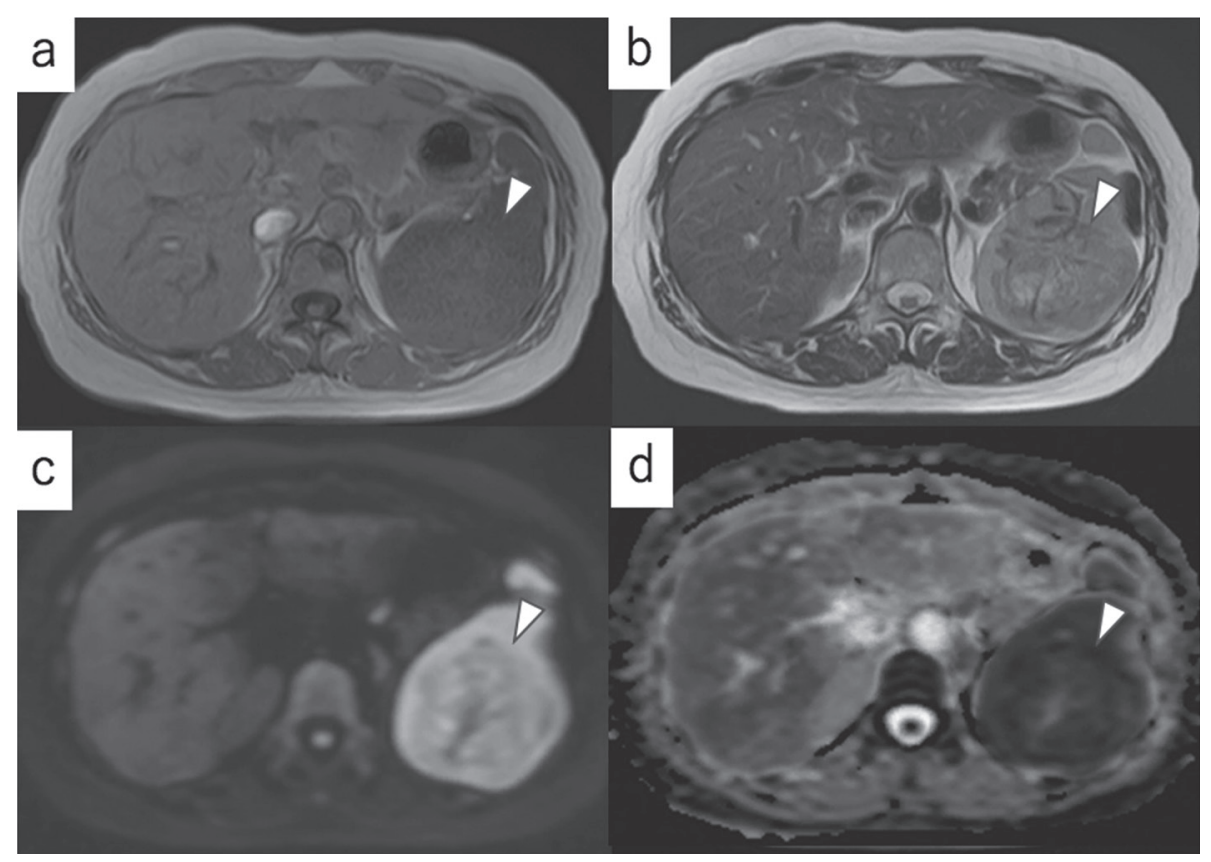

Fig. 2 MRI
a : T1 強調像. 脾実質に近い信号.
b : T2 強調像. 軽度の低信号を基調とし, 内部に不整形の高信号.
c：拡散強調像. 脾実質より若干劣る高信号.
d：ADC map. 脾実質と比較し低信号.

$7.5 \times 6.0 \mathrm{~cm}$ 大の結節性病変を認めた（Fig. 3)，豊富な 形質細胞，リンパ球浸潤と異型の目立たない紡錘形細 胞が増生し，中心には地図状壊死が見られた（Fig. $4 a, b)$. 免疫組織学的検查で紡鍾形細胞はSMA 陽性, EBER陽性，ALK陰性であり，背景にはCD21・ CD35・CD23が陽性を呈する滤胞樹状細胞が一部混在 していた (Fig. 4c, d). 以上から, 脾原発 EBV 関連
炎症性偽腫瘍様滤胞樹状細胞性腫瘍と診断した。

術後経過：血小板増加と脾静脈血栓を認めたため抗 凝固療法を行い, 術後21日目に退院となった。術後 7 カ月，再発なく経過中である.

\section{考察}

脾臓に発生する腫瘍は腫瘍全体の $0.64 \%$ と比較的稀 であり, 良性病変としては脾囊胞, リンパ管腫, 過誤 


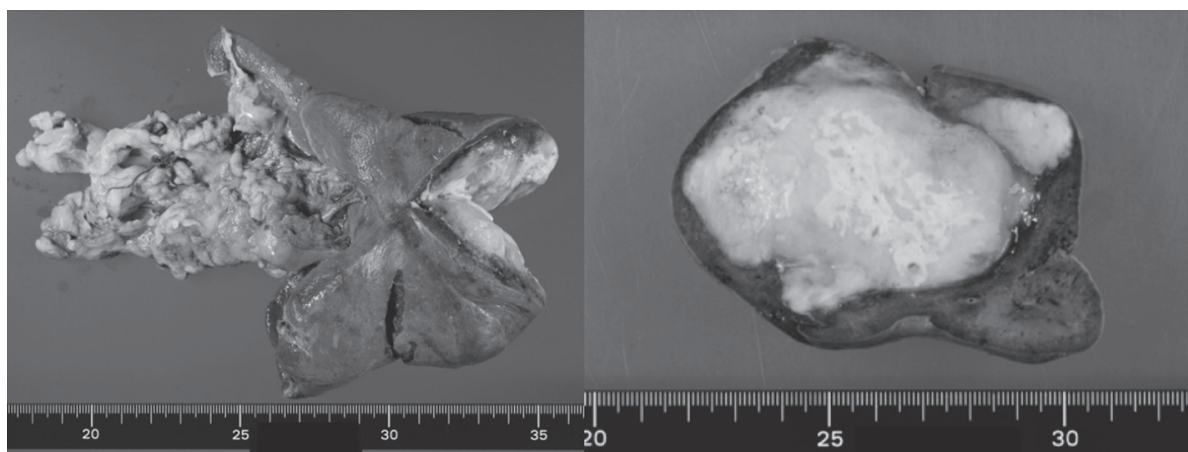

Fig. 3 摘出標本 : 脾蔵内に白色充実性を呈した $7.5 \times 6.0 \mathrm{~cm}$ 大の結節性病変を認めた.

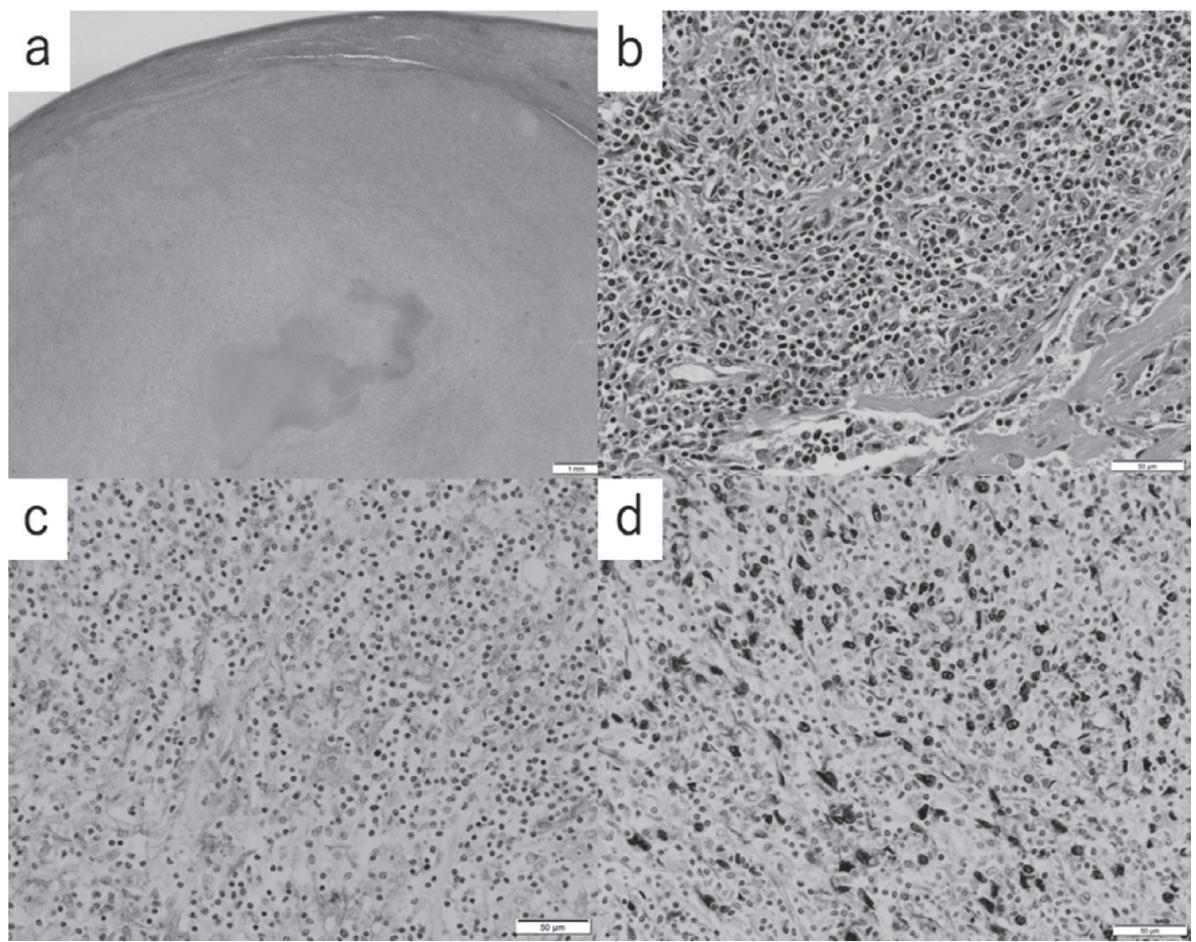

Fig. 4 摘出標本病理組織像

a (12.5倍), b (400倍)：H.E.. 豊富な形質細胞, リンパ球浸潤と紡錘形細胞が増生し, 中心に は地図状壊死を認める。

c (400倍)：CD35. 陽性を呈する滤胞樹状細胞が混在していた。

d (400倍) : EBER. 腫瘍細胞で陽性を示した.

腫, 膿瘍, 血管腫など, 悪性病変としては悪性リンパ腫, 転移性腫瘍, 血管肉腫などがある11). Epstein-Barr virus (EBV) 関連炎症性偽腫瘍様濾胞樹状細胞性腫瘍 (inflammatory pseudotumor-like follicular dendritic cell tumor : IPT-like FDC tumor) は炎症性偽腫瘍 (inflammatory pseudotumor：IPT) と濾胞樹状細胞 肉腫（follicular dendritic cell sarcoma：FDCS）の特 徵を持つが, 両者の亜型ではなく, 臨床病理学的に独 立した疾患単位を形成する稀な腫瘍である2). IPT は 組織学的にリンパ球や形質細胞, マクロファージとい った非特異的炎症性細胞の浸潤と紡錘形細胞の増生, 間質系組織の修復像によって特徴づけられる良性の結 


\begin{tabular}{|c|c|c|c|}
\hline 平均年齢 (歳) & $60.3(33-87)$ & 腫瘍径 (cm) & $6.1(1.5-22)$ \\
\hline 性別 & & $\operatorname{PET}-\mathrm{CT}(\mathrm{n}=6)$ & \\
\hline 男性 & 18 & 集積あり & $100 \%(6 / 6)$ \\
\hline 女性 & 24 & SUV max & $11.2(6.8-14.3)$ \\
\hline 記載なし & 1 & FDC 関連マーカー陽性率 & \\
\hline 症状 (重複あり) & & $\mathrm{CD} 21$ & $71.1 \%(27 / 38)$ \\
\hline 腹痛 & 10 & CD35 & $91.2 \%(31 / 34)$ \\
\hline 体重減少 & 2 & $\mathrm{CD} 23$ & $76.7 \%(23 / 30)$ \\
\hline 倦总感 & 2 & 治療 & \\
\hline 腹部膨満 & 1 & 脾臓摘出術 (腹腔鏡) & $36(9)$ \\
\hline 発熱 & 1 & 記載なし & 7 \\
\hline 無症状 & 29 & 転帰 & \\
\hline $\operatorname{MRI}(\mathrm{n}=8)$ & & 再発 & $0 \%(0 / 33)$ \\
\hline T1 (low/iso/high) & $0 / 7 / 1$ & 記載なし & 10 \\
\hline $\mathrm{T} 2$ (low/iso/high) & $4 / 2 / 2$ & 術後観察期間 (カ月) & $17.4(2-78)$ \\
\hline
\end{tabular}

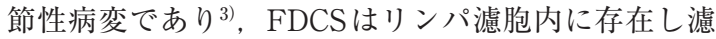
胞立体構造の支持や免疫複合体の補足・保持, B細胞 リンパ球への抗原提示などの機能を担う滤胞樹状細胞 から発生する腫瘍であり ${ }^{4)}$, FDC 関連マーカーである $\mathrm{CD} 21 \cdot \mathrm{CD} 35 \cdot \mathrm{CD} 23$ が陽性となる. EBV関連 IPTlike FDC tumorはIPTのように炎症性細胞浸潤を背 景とし, 紡錘形腫瘍細胞にFDC関連マーカーが発現 し, EBV 感染を認める稀な腫瘍である.

医学中央雑誌, PubMedで「脾臓」「炎症性偽腫瘍 様滤胞樹状細胞性腫瘍」,「Spleen」「Inflammatory pseudotumor-like follicular dendritic cell tumor」を キーワードに, 1983年〜2019年の期間で検索すると, これまでに42(例35) 27)が報告されており（会議録を除 く）, 自験例を加えた43例に関して検討した（Table 1)。平均年齢は60.3歳で, 男性18例, 女性24例, 不詳 1 例であった. 自覚症状は腹痛 10 例, 体重減少 2 例, 倦意感 2 例, 腹部膨満 1 例, 発熱 1 例, 無症状 29 例で あり(重複あり), 多くは偶然発見されたものであった。 腫瘍径は平均 $6.1 \mathrm{~cm}(1.5-22 \mathrm{~cm})$ で, PET-CTでは異 常集積を認める傾向があった。治療は記載のある報告 では全例で外科的切除が行われており, 術後の平均観 察期間は17.4力月で, 再発や転移, 死亡例は認めなか った.

診断には造影 CT P MRIが用いられ, 造影 CT で低 吸収を示し, MRIのT1 強調像で等信号, T2 強調像 では低信号を示すことが多いといわれている10). 自験 例では造影 $\mathrm{CT}$ で造影効果を認め, $\mathrm{T} 1$ 強調像で等信 号, T2 強調像で低信号の内部に不整形の高信号を呈
した．自験例を含めた今回の集計でも $\mathrm{T} 1$ 強調像で等 信号, T2 強調像で低信号を示す傾向があり, 脾腫瘍 において上記画像所見を認めた際は稀ではあるが本疾 患を念頭に置く必要がある. 確定診断は切除標本の病 理組織学的検査により行われる. 病理組織学的検査で はリンパ球，形質細胞を主体とする高度な炎症性細胞 の浸潤とともに, 滤胞樹状細胞に類似した紡錘形腫瘍 細胞が散在性に見られる ${ }^{328)}$. 免疫組織学的検査では, 紡錘形細胞はFDC関連マーカーであるCD21・ CD35・CD23のいずれかが陽性となり，これに加えin situ hybridization（ISH）法にてEBV encoded small RNA（EBER）陽性を示す13). FDC関連マーカーに ついて記載のあった報告例を集計すると, CD21・ CD35•CD23の陽性率は71.1\% (27/38), 91.2\% (31/34), $76.7 \%$ (23/30) であった. 自験例では豊富な形質細胞, リンパ球浸潤と紡錘形細胞が増生し, SMA 陽性, ALK 陰性, CD21·CD 35・CD23がいずれも陽性を示し, EBER-ISH 法にてEBVが検出されたことから EBV 関 連IPT-like FDC tumor と診断した。

EBVはヘルペスウイルス科に属する二本鎖DNA ウ イルスであり，Bリンパ球や上皮細胞に感染し胃癌や Burkittリンパ腫など多様な増殖性疾患の原因となり うる2930)。唾液を介して感染を広げる病原性ウイルス であり, 成人までに 9 割以上が既感染となり潜伏感染 の形で終生保持する ${ }^{29)}$. ウイルスゲノムは宿主染色体 に付着し, 細胞増殖に伴う染色体分裂に一致してウイ ルスゲノムも娘細胞に伝播し感染細胞を増殖させ, 一 部の持続感染細胞が増殖性に変化して腫瘍形成性を示 
す ${ }^{31)}$. 自験例でも EBER 陽性細胞の腫瘍性増殖を認め たことから, 感染した細胞の宿主ゲノムに変異を導入 することで細胞を腫瘍化へ導き, 増殖した感染細胞が 遺伝子変異を蓄積し腫瘍形成に至ったと推察される.

治療は診断も兼ねて外科的切除が行われる22)。自験 例を含め, 記載のある36例において全例で脾臓摘出が 施行されおり, 腹腔鏡での切除は自験例が 9 例目であ った. 脾蔵に対する腹腔鏡手術は解剖学的な位置関係 から開腹手術と比較し創の縮小と視野確保, 出血量の 低減, 入院期間の短縮が期待でき ${ }^{32)}$, 鑑別困難な脾腫 瘍において良性疾患では過大侵襲の軽減，悪性疾患で は術後治療の早期導入といった利点があると考える. 自験例では脾臓の腫大を認めたが，腹腔鏡下に良好な 視野のもと少量の出血量で手術を完遂し, 低侵襲に診 断・治療が行えた。また, 膵尾部と強い癒着を認めた 部位では, 出血や脺損傷を考慮し剥離に拘る意義は乏 しいと判断し一部脺組織を付けるように切除し, 膵尾 部合併切除とした. 本疾患の予後に関しては術後再発 や死亡をきたした報告例を認めないことから悪性度は 高くないと推察されるが, 自験例においても継続的な フォローが必要であると考えられる。

\section{結語}

鑑別困難な脾腫瘍においては, EBV 関連炎症性偽 腫瘍様濾胞樹状細胞性腫瘍も稀ながら念頭に置くべき であり, 腹腔鏡下脾蔵摘出術は適切な治療選択肢と考 える。

利益相反：なし

\section{文献}

1）小坂錦司, 吉川和彦, 井上雅文他 : 脾 inflammatory pseudotumorの 1 例. 日臨外会誌 2003 ; $64: 724-729$

2）榊原綾子, 下山芳江, 中村栄男 : EBV 関連炎症 性偽腫瘍様滤胞樹状細胞性腫瘍. 病理と臨 $2007 ; 25: 454-458$

3) 山村喜之, 斎藤崇宏, 蔦保暁生他：脾原発 $\mathrm{EBV}$ 関連炎症性偽腫瘍様樹状細胞肉腫の 1 例. 日臨外 会誌 $2014 ; 75: 1690-1694$

4）向山宣昭, 横井 久: 頸部に発生した滤胞樹状細 胞肉腫の 1 例. 頭頸部外 $2013 ; 23: 375-379$

5) Arber DA, Kamel OW, van de Rijin M, et al : Frequent presence of the Epstein-Barr virus in inflammatory pseudotumor. Hum Pathol 1995 ; $26: 1093-1098$

6) Cheuk W, Chan JKC, Shek TWH, et al : Inflammatory pseudotumor-like follicular dendritic cell tumor. Am J Surg Pathol 2001 ; 25 : 721 - 731
7) Horiguchi H, Matsui-Horiguchi M, Sakata H, et al : Inflammatory pseudotumor-like follicular dendritic cell tumor of the spleen. Pathol Int $2004 ; 54: 124-131$

8) Brittig F, Ajtay E, Jakso P, et al : Follicular dendritic reticulum cell tumor mimicking inflammatory pseudotumor of the spleen. Pathol Oncol Res $2004 ; 10: 57-60$

9) Sun OY, Hyoungsuk K, Beak-hui K, et al : Epstein-Barr virus-associated inflammatory pseudotumor-like follicular dendritic tumor in the spleen of a patient with diffuse large B cell lymphoma : a case report and review of the literature. Korean J Pathol 2007 ; 41 : $198-202$

10) Kiryu S, Takeuchi K, Shibahara J : Epstein-Barr virus-positive inflammatory pseudotumor and inflammatory pseudotumor-like follicular dendritic cell tumor. Br J Radiol 2009; $82: 67-71$

11) Rosenbaum L, Fekrazad MH, Vasef MA : Epstein-Barr virus-assosiated inflammatory pseudotumor of the spleen : report of two cases and review of the literature. J Hematopathol 2009 ; $2: 127-131$

12）高橋一徳, 矢嶋信久, 中山義人他：脾臓原発の炎 症性偽腫瘍型滤胞樹状細胞肉腫例. 診断病理 $2010 ； 27: 229-232$

13）稲村純季, 佐藤一也, 及川太他：脾原発 $\mathrm{EBV}$ 関連炎症性偽腫瘍様滤胞樹状細胞性腫瘍の 1 例. 旭川厚生病医誌 $2011 ; 21: 69-74$

14) Choe JY, Go H, Jeon YK, et al : Inflammatory pseudotumor-like follicular dendritic cell sarcoma of the spleen : a report of six cases with increased IgG4-positive plasma cells. Pathol Int 2013 ; 63 : $245-251$

15) Kim HJ, Kim JE, Kang GH, et al : Inflammatory Pseudotumor-like Follicular Dendritic Cell Tumor of the Spleen with Extensive Histiocytic Granulomas and Necrosis : A Case Report and Literature Review. Korean J Pathol 2013 ; 47 : $599-602$

16) Asano MO, Ito $Y$, Nagao $T$, et al : Epstein-Barr virus-associated inflammatory pseudotumorlike follicular dendritic cell tumor of the spleen without recurrence for 3 years after splenectomy. J Case Rep Med 2013 ; 2 : ID235715

17) Rao L, Yang $Z$, Wang $X$, et al : Imaging findings of inflammatory pseudotumor-like follicular dendritic cell tumor of spleen. Clin Nucl Med 2014 ; $39: 286-289$

18) Vardas K, Manganas D, Papadimitriou G, et al : Splenic inflammatory pseudotumor-like follicular dendritic cell tumor. Case Rep Oncol 2014 ; $7: 410-416$ 
19) Ge R, Liu C, Yin X, et al : Clinicopathologic characteristics of inflammatory pseudotumor-like follicular dendritic cell sarcoma. Int J Clin Exp Pathol $2014 ; 7: 2421-2429$

20) Li XQ, Cheuk W, Lam PW, et al : Inflammatory pseudotumor-like follicular dendritic cell tumor of liver and spleen : granulomatous and eosinophil-rich variants mimicking inflammatory or infective lesions. Am J Surg Pathol 2014 ; 38 : $646-653$

21) Loughlin P, Brady A, Devlin E, et al : EpsteinBarr virus positive inflammatory pseudo-tumor of the spleen : A case report and literature review. Int J Surg Case Rep $2014 ; 5$ : 186-188

22) 小池佳勇, 長坂 暢, 橋本瑞生他: 脾 $\mathrm{EBV}$ 関連 炎症性偽腫瘍様滤胞樹状細胞性腫瘍の 1 例. 日臨 外会誌 $2015 ; 76: 2549-2554$

23) Bui PL, Vicens RA, Westin JR, et al : Multimodality imaging of Epstein-Barr virus-associated inflammatory pseudotumor-like follicular dendritic cell tumor of the spleen : case report and literature review. Clin Imaging 2015 ; 39 : $525-$ 528

24) Kitamura Y, Takayama $Y$, Nishie A, et al : Inflammatory Pseudotumor-Like Follicular Dendritic Cell Tumor of the Spleen : Case Report and Review of the Literature. Magnet Reso- nance Med Sci $2015 ; 14: 347$ - 354

25) Hang JF, Wang LC, Lai CR : Cytological features of inflammatory pseudotumor-like follicular dendritic cell sarcoma of spleen : A case report. Diagn Cytopathol 2017 ; 45 : 230-234

26) Li X, Shi Z, You R, et al : Inflammatory Pseudotumor-Like Follicular Dendritic Cell Sarcoma of the Spleen : Computed Tomography Imaging Characteristics in 5 Patients. J Comput Assist Tomogr $2018 ; 42: 399-404$

27) Kwon $\mathrm{H}$ : Inflammatory pseudotumor-like follicular dendritic cell tumor of the spleen. Turk J Gastroenterol $2018 ; 29$ : $128-130$

28）福里利夫, 熊谷有紗 : 炎症性偽腫瘍およびその類 似病変の鑑別診断. Liver Cancer 2009; 15 ： $145-150$

29）岩切大：EBウイルスによる発癌の分子機構. ウイルス $2014 ; 64: 49-56$

30）村田貴之：EBウイルスの感染様式とがん. ウイ ルス $2014 ; 64: 95-104$

31）吉山裕規，金廣優一, Kim H他：感染に伴って起 こるがん：Epstein-Barrウイルス関連胃癌を中 心に. 島根医 $2016 ; 36: 1-7$

32) 永山 稔, 木村康利, 平田公一他：腹腔鏡下脾臓 摘出術の有用性 開腹術との比較による臨床的検 討. 北海道外科誌 $2007 ; 52: 144-147$

\section{A CASE OF LAPAROSCOPICALLY RESECTED EBV-RELATED INFLAMMATORY PSEUDOTUMOR-LIKE FOLLICULAR DENDRITIC CELL TUMOR OF THE SPLEEN}

\section{Tomoya HIRAI'), Yuki HOMMA ${ }^{1)}$, Yasuhiro SHIMIZU'), Takahumi KUMAMOTO ${ }^{1)}$, Ryusei MATSUYAMA ${ }^{1)}$, Shoji YAMANAKA ${ }^{2)}$ and Itaru ENDO ${ }^{1)}$}

Departments of Gastroenterological Surgery ${ }^{1)}$ and Diagnostic Pathology ${ }^{2)}$, Yokohama City University School of Medicine

A 53-year-old woman was referred to our department when a splenic tumor was detected by a CT scan performed for diabetes insipidus. The abdominal CT had revealed uneven contrast-enhanced effects in the spleen indicating the presence of a mass with a maximum diameter of $7.7 \mathrm{~cm}$. A PET-CT also detected abnormal accumulation in the same region. Although an MRI was performed, a definite diagnosis could not be made based on the imaging findings, and malignancy could not be ruled out. Therefore, we decided to perform laparoscopic splenectomy for diagnostic treatment. Histopathological examination revealed advanced inflammatory cell infiltration and spindle-shaped cell proliferation, while immunostaining revealed $\mathrm{CD} 21, \mathrm{CD} 35, \mathrm{CD} 23$, and EBER positivity. Based on the above results, the patient was diagnosed as EBV-related inflammatory pseudotumor-like follicular dendritic cell tumor of the spleen. This is a rare tumor characterized by inflammatory pseudotumor, follicular dendric cell sarcoma and EBV infection. Although uncommon, EBV-related inflammatory pseudotumor-like follicular dendritic cell tumors should be considered in cases of indeterminate splenic tumors. Laparoscopic splenectomy may be an appropriate treatment option.

Key words : spleen, laparoscopic surgery, inflammatory pseudotumor-like follicular dendritic cell tumor 